\title{
PELATIHAN MEMBUAT KREASI BENDA FUNGSIONAL DARI KAIN FLANEL UNTUK MENUMBUHKAN JIWA WIRAUSAHA DI SEKOLAH LUAR BIASA NEGERI BAGIAN B SINGARAJA
}

\author{
oleh, \\ Made Diah Angendari \\ Jurusan Pendidikan Kesejahteraan Keluarga \\ Fakultas Teknik dan Kejuruan \\ Universitas Pendidikan Ganesha
}

\begin{abstract}
ABSTRAK
Kegiatan Pengabdian pada Masyarakat ini bertujuan untuk memberikan pelatikan membuat kreasi benda funsioanal menggunakan kain flanel yang siap dijual dan mampu menumbuhkan jiwa wirausaha serta untuk mengetahui tanggapan siswa Sekolah Luar Biasa Bagian B terhadap pelatihan pembuatan kreasi benda fungsioal menggunakan bahan kain flanel sekaligus menumbuhkan jiwa wirausaha. Metode kegiatan pengabdian masyarakat ini menggunakan metode ceramah, demontrasi langsung dipraktekkan oleh peserta, serta tanya jawab. Metode ceramah digunakan untuk menyampaikan pengetahuan secara umum tentang kreasi produk fungsional dan kain flanel, yaitu meliputi sejarah kain flanel, kegunaan kain flanel, macam-macam kain flanel. Demontrasi digunakan untuk memberikan keterampilan langsung mengenai proses pembuatan kreasi produk fungsional yang berbahan baku kain flnnel, peralatan yang diperlukan serta bahan digunakan dalam pembuatan produk fungsional. Tanya jawab digunakan untuk melengkapi hal-hal yang belum terakomodasi oleh kedua metode di atas. Pelatihan ini melibatkan dosen Jurusan Pendidikan Kesejahteraan Keluarga yang bekerja sama dengan Sekolah Luar Biasa Bagian B Singaraja yang melibatkan siswi SD, SMP dan SMA sebagai subyek sasaran. Hasil pelatihan pembuatan kreasi benda fungsional dari kain flanel dapat dinyatakan berhasil. Hal ini dapat dilihat dari: (1) Kehadiran peserta sesuai dengan target yaitu 91\% (20 dari 22 siswa) (2) hasil pelatihan dinyatakan sangat baik sesuai dengan analisis rubrik penilaian kinerja. (3) Peserta sangat antusias mengikuti pelatihan yang dilihat dari keseriusan mengikuti pelatihan, banyaknya produk yang dibuat dan mencoba membuat produk dengan kresai masing-masing.
\end{abstract}

Kata Kunci: benda fungsional, kain flanel, wirausaha

\section{Pendahuluan}

Anak berkebutuhan khusus (Heward) adalah anak dengan karakteristik khusus yang berbeda dengan anak pada umumnya tanpa selalu menunjukan pada ketidakmampuan mental, emosi atau fisik. Yang termasuk kedalam ABK antara lain: tunanetra, 
tunarungu, tunagrahita, tunadaksa, tunalaras, kesulitan belajar, gangguan prilaku, anak berbakat, anak dengan gangguan kesehatan. istilah lain bagi anak berkebutuhan khusus adalah anak luar biasa dan anak cacat. Sebagai individu yang memiliki kekurangan maka mereka pada umumnya sering dianggap kurang memiliki rasa percaya diri dan cenderung menutup diri dari lingkungannya. Pandangan masyarakat yang kurang positif juga justru menambah beban permasalahan bagi para penyandang cacat. Sebenarnya dengan keterbatasan-keterbatasan yang ada pada mereka harus disikapi secara positif agar mereka dapat dikembangkan seoptimal mungkin potensinya dan diharapkan dapat memberikan kontribusi positif bagi keluarga, lingkungan, masyarakat, serta pembangunan bangsa.

Sekolah Luar Biasa Bagian B Singaraja Bali adalah sekolah khusus untuk anakanak Tunarungu. Tunarungu adalah individu yang memiliki hambatan dalam pendengaran baik permanen maupun tidak permanen. Di Sekolah ini terdapat siswa Sekolah Dasar 51 orang, Sekolah Menengah Pertama 15 orang dan Sekolah Menengah Atas 7 orang. Berbagai upaya telah banyak dan tak pernah berhenti dilakukan mulai dari tingkat pusat hinggga di tingkat sekolah untuk mengembangkan pendidikan bagi ABK di SLB B yang semakin bermutu, namun realita yang ada masih menunjukkan belum tercapainya apa yang dicita-citakan. Mutu ABK selama masih dalam proses hingga setelah lulus dari SLB masih diragukan untuk mampu hidup bermasyarakat secara wajar. Hal ini merupakan tantangan dan kewajiban bagi Universitas Pendidikan Ganesha, melalui Lembaga Pengabdian Masyarakat (LPM) merencanakan dan melaksanakan pendidikan ketrampilan bagi anak-anak SLB.

Dipandang perlu untuk memberdayakan anak-anak SLB Bagian B untuk meningkatkan ketrampilan di bidang busana (kerajinan tangan). Mengingat mereka sudah memiliki ketrampilan dasar menjahit, membuat ketrampilan dan tersedianya alatalat menjahit di sekolah. Menurut pendapat Sutrisno (1997) hal yang dapat kita lakukan dalam pembinaan anak-anak cacat adalah melakukan pendampingan pada mereka dalam upaya peningkatan kualitas sumberdaya manusia, sehingga pada waktunya nanti mereka bisa memasuki atau justru dapat menciptakan lapangan kerja. Adapun program pelatihan yang akan diberikan adalah membuat kreasi benda fungsional dengan menggunakan kain flanel. Dipilihnya kain flanel sebagai bahan utama pembuatan 
produk kerajinan karena kain flanel mudah didapat dan harganya tidak terlalu mahal, sedangkan kreasi fungsional yang akan dibuat adalah berupa benda-benda berupa souvenir yang memiliki fungsi bagi kehidupan sehari-hari. Kreasi benda fungsional yang akan dibuat adalah gantungan kunci, jepit rambut, tempat pensil, tempat HP, ikat rambut, bros, pembatas buku, dan lain-lain

Universitas Pendidikan Ganesha, membawahi Fakultas Teknik dan Kejuruan (FTK) yang memiliki jurusan Pendidikan Kesejahteraan Keluarga. Pada sub program tata Busana 65\% kurikulumnya mengajarkan praktikum aneka jenis ketrampilan. Oleh karena itu kegiatan dalam bentuk Pengabdian Masyarakat ini sangat relevan untuk memecahkan permasalahan yang ada di Sekolah Luar Biasa Bagian B Singaraja.

Permasalahan yang ada pada berupa kondisi ekonomi Bangsa Indonesia saat ini, bukanlah hal yang mudah untuk memperoleh pekerjaan, apalagi bagi anak-anak Sekolah Luar Biasa Bagian B yang memiliki kekurangan fisik. Hal ini tentunya menjadi permasalahan yang rumit, jika anak-anak SLB bagian B tersebut tidak dipersiapkan untuk mencari peluang di dunia usaha, dengan kata lain berwirausaha mandiri. Sedangkan di sekolah tersebut banyak terdapat alat-alat menjahit yang belum dipergunakan secara optimal. Akar dari permasalahan adalah siswa SLB Bagian B merupakan sekolah khusus tunarungu dimana mereka cacat dalam hal pendengaran yang kebanyakan sulit untuk mencari pekerjaan, dimana anak-anak tersebut belum pernah dilatih untuk membuat kreasi benda fungsional, dan di sekolah tersebut sudah tersedia alat-alat menjahit yang belum digunakan secara optimal.

Oleh karena itu sudah seharusnya perguruan tinggi melalui penerapan Dharma ke 3 yaitu Pengabdian Pada Masyarakat memberikan kontribusi untuk memecahkan persoalan tersebut. Realisasi pemecahan masalah terhadap kerangka pemecahan masalah dilakukan melalui peningkatan ketrampilan dalam pelatihan pembuatan kreasi benda fungsional menggunakan bahan kain flannel yang siap jual yang mampu menumbuhkan jiwa wirausaha. Dengan adanya pelatihan ini diharapkan siswa Selolah Luar Biasa Bagian B (siswa SMP dan SMA) dapat menerapkan berbagai ketrampilan yang akan diberikan, dan selalu menggali ide baru untuk berinovasi dalam berkarya. Selanjutnya dengan penguasaan wawasan dan ketrampilan tersebut para siswa lebih siap untuk mandiri, dan menjadi insane yang produktif. 
Kegiatan pengabdian ini dilaksanakan selama 6 bulan yang terbagi dalam tiga tahap yaitu: (1) tahap perencanaan, (2) tahap pelaksanaan, (3) tahap evaluasi. Tahap perencanaan telah ditetapkan hal-hal sebagai berikut: tempat/lokasi kegiatan dipilih di Sekolah Luar Biasa Negeri Bagian B Singaraja Bali, yang terletak di Jl Veteran Singaraja. Jenis kegiatan berupa pelatihan membuat kreasi benda fungsional menggunakan kain flannel untuk menumbuhkan jiwa berwirausaha. Tahap pelaksanaan berupa penyajian materi secara teori selama 1 hari dilanjutkan dengan membuat kreasi benda fungsional (gantungan kunci, tempat $\mathrm{Hp}$, tempat pensil. pembatas buku, bros, jepit rambut, ikat rambut, boneka, dll). Tahap yang terakhir adalah evaluasi akhir dan pelaporan.

\section{Metode Pelaksanaan Kegiatan}

Kegiatan pengabdian pada masyarakat (P2M) menggunakan metode dalam bentuk pelatihan keterampilan melalui ceramah, demontrasi dan Tanya jawab dilaksanak selama 6 bulan. Adapun tahapan-tahapan dalam pelaksanaan kegiatannya (1) Ceramah digunakan untuk menyampaikan pengetahuan secara umum tentang kreasi produk fungsional dan kain flanel, yaitu meliputi sejarah kain flannel, kegunaan kain flannel, macam-macam kain flannel, (2) Demontrasi digunakan untuk memberikan keterampilan langsung mengenai proses pembuatan kreasi produk fungsional yang berbahan baku kain flnnel, peralatan yang diperlukan serta bahan digunakan dalam pembuatan produk fungsional, (3) Tanya jawab digunakan untuk melengkapi hal-hal yang belum terakomodasi oleh kedua metode diatas, (4) Pelatihan pembuatan kreasi produk fungsional dari bahan kain flanel ditujukan kepada siswa dengan melibatkan seluruh peserta pelatihan, dan (5) Evaluasi hasil akhir.

Khalayak sasaran yang trategis untuk masalah ini adalah siswa Sekolah Luar Biasa bagian B Singaraja, sebanyak 20 orang yang sedang mengenyam pendidikan SD sebanyak 6 orang, SMP sebanyak 7 orang dan SMA 7 orang. Dipilihnya siswa setingkat SMP dan SMA, sebab mereka tergolong usia yang sangat produktif baik dilihat dari kecepatan kerja, kecepatan belajar, tingkat antusiasme, memilki daya kreativitas yang tinggi, mereka sudah memiliki ketrampilan memadai untuk tumbuh menjadi insan mandiri dan produktif. Pelatihan ini melibatkan dosen Jurusan 
Pendidikan Kesejahteraan Keluarga (Tata Busana) yang mengampu mata Kuliah Seni Kerajinan Tangan (SKT) di bantu oleh guru-guru keterampilan dalam berkomunikasi dengan siswa. Bekerja sama dengan Sekolah Luar Biasa Bagian B Singaraja yang melibatkan siswa SD, SMP dan SMAsebagai subyek sasaran. Pengabdian ini dilakukan dalam upaya mengadakan hubungan yang erat melalui pererapan disiplin ilmu khususnya dibidang Tata Busana. Siswa dapat memperoleh pengetahuan dan keterampilan tentang pembuatan produk kreasi fungsional berbahan baku kain flanel yang lebih berkualitas dan memiliki nilai ekonomis yang lebih baik.

Tingkat keberhasilan pelatihan ini dilakukan melalui pengamatan langsung melalui penilaian kinerja dan hasil produk pada peserta dalam proses persiapan, pelaksanaan, dan evaluasi dalam pembuatan kreasi produk fungsional dari bahan kain flanel dilakukan oleh instruktur dengan mengacu pada indikator yang tercantun dalam rubrik yang telah disiapkan. Adapun model rubrik yang digunakan adalah rubrik untuk menilai ketrampilan proses sebagai berikut:

Tabel 1 Check list proses pembuatan benda fungsional

\begin{tabular}{|c|c|c|c|c|c|}
\hline \multirow[t]{2}{*}{ No } & \multirow[t]{2}{*}{ Ketrampilan yang diamati } & \multicolumn{4}{|c|}{ Skala Nilai } \\
\hline & & 4 & 3 & 2 & 1 \\
\hline 1 & Persiapan (Pemilihan bahan, pengukuran, penyiapan alat) & & & & \\
\hline 2 & Penggunaan Peralatan yang benar & & & & \\
\hline 3 & Ketepatan langkah-langkah membuat kreasi produk fungsional & & & & \\
\hline 4 & $\begin{array}{l}\text { Kesesuaian hasil akhir yang dipresentasikan menurut kreteria } \\
\text { yang diharapkan }\end{array}$ & & & & \\
\hline 5 & Menata peralatan setelah selesai kegiatan & & & & \\
\hline 6 & Kreatifitas produk & & & & \\
\hline 7 & Kerapian produk & & & & \\
\hline 8 & Kombinasi warna & & & & \\
\hline & $4=$ sangat baik, $3=$ baik, $2=$ cukup, $1=$ kurang & & & & \\
\hline
\end{tabular}

Selanjutnya hasil akhir penilaian kinerja dirata-ratakan dan dikonversi menggunakan pedoman konversi sebagai berikut:

Tabel 2 Pedoman Hasil Evaluasi

\begin{tabular}{|c|c|c|c|}
\hline No & Rentangan & Nilai & Katagori \\
\hline 1 & $85-100$ & 4 & Sangat baik \\
\hline 2 & $70-84$ & 3 & Baik \\
\hline 3 & $55-69$ & 2 & Cukup \\
\hline 4 & $<54$ & 1 & Kurang \\
\hline
\end{tabular}




\section{Hasil dan Pembahasan}

Kegiatan pelatihan pembuatan kreasi benda fungsional dari kain flanel di Sekolah Luar Biasa Bagian B Singaraja dilaksanakan pada hari Sabtu tanggal 22 September 2012. Kegiatan dimulai pukul 07.30 sampai dengan pukul 11.30 wita. Kegiatan diawali dengan mengumpulkan peserta di ruang guru yang sekaligus sebagai tempat pelatihan. Target peserta 22 orang yang terdiri dari siswa SMA dan SMP yang berjenis kelamin laki-laki dan perempuna. Namun kepala sekolah meminta untuk pelatihan ini hanya memibatkan siswa perempuan saja, dan ditambah dengan siswa perempuan dari kelas 46 SD. Sehinga peserta semuanya adalah 22 orang yang terdiri dari siswa SD, SMP dan SMA. Peserta yang berjumlah 20 orang dibagi dalam tiga kelompok, yaitu kelompok SD, kelompok SMP, dan kelompok SMA. Acara selanjutnya instruktur (Made Diah Angendari) dibantu oleh guru-guru keterampilan SD, SMP dan SMA menyampaikan hal-hal yang berkaitan dengan cara membuat kreasi benda fungsional melalui metode ceramah. Peserta terlihat antusias mengikuti kegiatan ini, dan mereka sangat tertarik untuk mencoba. Selanjutnya instruktur membagi kelompok menjadi tiga.

Kegiatan perkelompok membuat kreasi benda fungsional yang berbeda-beda. Kelompok SD yang berjumlah 5 orang membuat kreasi benda berupa gantungan kunci, jepit rambut, gantungan hp, bros, pembatas buku, dan boneka. Sedangkan kelompok SMP membuat produk tempat HP, dan kelompok SMA membuat tempat pensil. Adapun kegiatan yang dilakukan pada proses pembuatan benda fungsional pada dasarnya sama, yaitu peserta diberi kesempatan untuk memilih produk yang akan dibuat, pembuat pola, menggunting sesuai dengan bentuk, menjahit dengan tusuk feston, memberi hiasan dan memasang pernak-pernik sehingga menjadi bentuk yang diharapkan. Setiap peserta dibebaskan membuat kreasi benda funsional, baik meniru contoh-contoh yang sudah disiapkan atau membuat kresai sendiri. Setiap peserta yang sudah menyelesaikanproduknya diberi kesempatan untuk membuat beda lain yang mereka inginkan.

Hasil kegiatan pelatihan pembuatan kreasi benda fungsional dari kain flanel secara umum dapat dikatakan berhasil. Hal ini dapat dilihat dari persentase kehadiran peserta mencapai 91\%, sedangkan berdasarkan perencanaan, proses dan hasil praktik dapat dijabarkan sebagai berikut: 
Tabel 3 Rekapitulasi data hasil kegiatan pembuatan kresai benda fungsional dari kain flanel

\begin{tabular}{|c|c|c|c|c|}
\hline No Peserta & Perencanaan & Proses & Hasil & Total \\
\hline 1 & 4 & 3 & 4 & 11 \\
\hline 2 & 4 & 4 & 4 & 12 \\
\hline 3 & 3 & 4 & 3 & 10 \\
\hline 4 & 3 & 3 & 3 & 9 \\
\hline 5 & 4 & 4 & 4 & 12 \\
\hline 6 & 3 & 4 & 4 & 10 \\
\hline 7 & 4 & 3 & 4 & 11 \\
\hline 8 & 4 & 3 & 4 & 11 \\
\hline 9 & 4 & 4 & 4 & 12 \\
\hline 10 & 3 & 4 & 3 & 10 \\
\hline 11 & 3 & 3 & 3 & 9 \\
\hline 12 & 4 & 4 & 4 & 12 \\
\hline 13 & 3 & 4 & 4 & 10 \\
\hline 14 & 4 & 3 & 4 & 11 \\
\hline 15 & 3 & 3 & 4 & 10 \\
\hline 16 & 4 & 4 & 4 & 12 \\
\hline 17 & 3 & 4 & 4 & 11 \\
\hline 18 & 4 & 4 & 4 & 12 \\
\hline 19 & 4 & 4 & 3 & 11 \\
\hline 20 & 4 & 3 & 4 & 11 \\
\hline Total & 72 & 72 & 75 & $91,3 \%$ \\
\hline$\%$ & $90 \%$ & $90 \%$ & $93,8 \%$ & \\
\hline
\end{tabular}

Berdasarkan data pada Tabel 3 dapat dikatakan dapat dikatakan bahwa pada perencanaan pembuatan produk kreasi funsional dari kain flanel memperoleh persentase $90 \%$ dalam kategori sangat baik, tahap proses pembuatan produk kreasi benda funsional mencapai $90 \%$ dalam kategori sangat baik, dan pada tahap hasil memperoleh persentase 93,8\%. Jadi dapat disimpulkan bahwa pembuatan produk kreasi benda funsional dari kain flanel berhasil sesuai dengan harapan. Sementara hasil kegiatan perkelompok yang terdiri dari tiga kelompok, yaitu kelompok SMA membuat tempat Hp, kelompok SMP membuat tempat pensil, kelompok SD membuat gantungan kunci, jepitan rambut, ikat rambut, dan pembatas buku. Berdasarkan evaluasi didapatkan hasil sebagai berikut:

Tabel 4 Rekapitulasi data hasil kegiatan pembuatan kresai benda fungsional (tempat HP) 


\begin{tabular}{|c|c|c|c|c|}
\hline No Peserta & Perencanaan & Proses & Hasil & Total \\
\hline 1 & 4 & 3 & 4 & 11 \\
\hline 2 & 4 & 4 & 4 & 12 \\
\hline 3 & 3 & 4 & 3 & 10 \\
\hline 4 & 3 & 3 & 3 & 9 \\
\hline 5 & 4 & 4 & 4 & 12 \\
\hline 6 & 3 & 4 & 4 & 10 \\
\hline 7 & 4 & 3 & 4 & 11 \\
\hline Total & 25 & 24 & 26 & \\
\hline$\%$ & $89,9 \%$ & $85,7 \%$ & $92,9 \%$ & $89,3 \%$ \\
\hline
\end{tabular}

Berdasarkan data pada Tabel 4 dapat dikatakan dapat dikatakan bahwa pada perencanaan pembuatan produk tempat $\mathrm{Hp}$ memperoleh persentase $89,9 \%$ dalam kategori sangat baik, tahap proses pembuatan produk tempat Hp mencapai 85,7\% dalam kategori sangat baik, dan pada tahap hasil memperoleh persentase 92,9\%. Jadi dapat disimpulkan bahwa pembuatan produk tempat $\mathrm{Hp}$ dari kain flanel berhasil sesuai dengan harapan.

Sementara itu sebagian siswa (kelompok SMP) membuat produk tempat pensil dari kain flanel. Berdasarkan evaluasi yang dilakukan instruktur diperoleh hasil sebagai yang dapat dilihat pada Tabel 5.

Tabel 5 Rekapitulasi data hasil kegiatan pembuatan kresai benda fungsional (tempat pensil)

\begin{tabular}{|c|c|c|c|c|}
\hline $\begin{array}{c}\text { No } \\
\text { Peserta }\end{array}$ & Perencanaan & Proses & Hasil & Total \\
\hline 1 & 4 & 3 & 4 & 10 \\
\hline 2 & 3 & 4 & 4 & 11 \\
\hline 3 & 3 & 4 & 4 & 11 \\
\hline 4 & 4 & 3 & 3 & 10 \\
\hline 5 & 4 & 4 & 4 & 11 \\
\hline 6 & 4 & 3 & 3 & 10 \\
\hline 7 & 4 & 3 & 4 & 10 \\
\hline Total & 24 & 24 & 25 & \\
\hline$\%$ & $85,7 \%$ & $85,7 \%$ & $89,3 \%$ & $86,9 \%$ \\
\hline
\end{tabular}

Berdasarkan data pada Tabel 5 dapat dikatakan dapat dikatakan bahwa pada perencanaan pembuatan produk tempat pensil memperoleh persentase $85,7 \%$ dalam 
kategori sangat baik, tahap proses pembuatan produk tempat pensil mencapai $85,7 \%$ dalam kategori sangat baik, dan pada tahap hasil memperoleh persentase $86,9 \% \%$. Jadi dapat disimpulkan bahwa pembuatan produk tempat Hp dari kain flanel berhasil sesuai dengan harapan. Sedangkan kelompok siswa yang lainnya (kelompok SD) membuat produk karet rambut, gantungan kunci dan jepit rambut dari kain flanel. Berdasarkan evaluasi yang dilakukan instruktur diperoleh hasil seperti dapat dilihat pada Tabel 6 .

Tabel 6 Rekapitulasi data hasil kegiatan pembuatan kresai benda fungsional (gantungan kunci, karet rambut, jepit rambut, pembatas kuku)

\begin{tabular}{|c|c|c|c|c|}
\hline No Peserta & Perencanaan & Proses & Hasil & Total \\
\hline 1 & 3 & 3 & 4 & 10 \\
\hline 2 & 4 & 4 & 4 & 12 \\
\hline 3 & 3 & 4 & 4 & 11 \\
\hline 4 & 4 & 4 & 4 & 12 \\
\hline 5 & 4 & 4 & 3 & 11 \\
\hline 6 & 4 & 3 & 4 & 11 \\
\hline Total & 22 & 22 & 23 & \\
\hline$\%$ & $91,7 \%$ & $91,7 \%$ & $95,8 \%$ & $93,1 \%$ \\
\hline
\end{tabular}

Berdasarkan data pada Tabel 6 dapat dikatakan dapat dikatakan bahwa pada perencanaan pembuatan produk gantungan kunci, jepit rambut, ikat rambut dan pembatas buku memperoleh persentase $91,7 \%$ dalam kategori sangat baik, tahap proses pembuatan produk gantungan kunci, jepit rambut, ikat rambut dan pembatas buku mencapai 91,7\% dalam kategori sangat baik, dan pada tahap hasil memperoleh persentase $95,8 \% \%$. Jadi dapat disimpulkan bahwa pembuatan produk gantungan kunci, jepit rambut, ikat rambut dan pembatas buku dari kain flanel berhasil sesuai dengan harapan.

Berdasarkan hasil kegiatan P2M yang telah dipaparkan pada hasil, bahwa kegiaran pengabdian ini mendapat respon yang positif dari para peserta, guru-guru dan kepala sekolah Luar Biasa Bagian B Singaraja, dimana para peserta sangat antusias mengikuti kegiatan, dan hasilnya juga sangat baik, begitu juga dengan guru-guru yang dengan senang hati membantu dalam proses awal sampai akhir.

Di sisi lain masih ditemukan beberapa kendala dalam pelaksanaan, misalnya menentukan waktu, karna pelatihan ini dijadwalkan hari karena hari Sabtu semua 
siswa/kelas mendapatkan pelajaran keterampilan, sementara jadwal disekolah banyak liburnya misalnya libur kenaikan kelas, libur hari raya Idul fitri, Libur galungan dan Kuningan, perayaan 17 Agustus dan kegiatan-kegiatan lain yang diselenggarakan pada hari Sabtu. Produk kreasi benda fungsional yang dibuat sesuai dengan harapan, instruktur menargetkan pembuatan tujuh benda fungsinal, dan target tersebut terpenuhi. Semua benda fungsional yang diberikan dapat diselesaikan dengan baik. Adapun produk fungsional tersebut adalah tempat $\mathrm{Hp}$, tempat pensil, gantungan kunci, jepit rambut, ikat rambut, pembatas buku, dan boneka. Namun demikian, kerjasama yang proaktif antar siswa untuk meyelesaikan setiap tugas seperti tempat Hp, tempat pensil, gantungan kunci, jepit rambut, ikat rambut, pembatas buku, dan boneka, mereka kerjakan dengan penuh tanggung jawab. Hal ini mengisyaratkan bahwa mereka sangat disiplin dengan waktu, walaupun mereka memiliki kekurangan yaitu tidak bisa mendengan dan berbicara, tetapi mereka punya semangat yang besar untuk belajar.

\section{Penutup}

Berdasarkan uraian pada hasil dan pembahasan di atas, maka dapat disimpilkan sebagai berikut: (1) Pelaksanaan kegiatan pelatihan pembuatan produk kreasi benda fungsional dari kain flanel telah berhasil membuat tempat HP, tempat pensil, gantungan kunci, ikat rambut, jepit rambut, pembatas buku dan boneka, dengan persentase terhadap setiap tahapan:perencanaan, proses, dan hasil berturut-turut $90 \%, 90 \%$ dan 92,8\% dalam kategori sangat baik, dan (2) Tanggapan siswa terhadap pelaksanaan kegiatan pelatihan pembuatan kreasi benda funsional dari kain flanel ini sangat baik. Hal ini dapat dilihat dari idikator kehadiran siswa mencapai 92\% dari target, dan selama kegiatan berlangsung mereka sangat antusias mengikuti kegiatan dari awal sampai akhir kegitan.

Kegiatan P2M di Sekolah Luar Biasa bagian B Singaraja, mendapat respon yang positif, tentunya hal ini bisa ditindaklanjuti pada waktu berikutnya, dengan bidangbidang yang lain misalnya menjahit, pembuatan motif dengan teknik jumputan, dan juga bidang tata rias, sehingga siswa memiliki ketrampilan yang mencukupi untuk bekal hidupnya nanti. 


\section{DAFTAR PUSTAKA}

Imawati, Emi Risna. 2006. Aksesori \& Perengkaan Anak Dari kain Felt. PT Gramnedia Pustaka Utama: Jakarta.

Lunaya art. 15 April 2010.Petunjuk dasar Berkresai dengan Kain Flanel. http://LunayaArtflanel.htm. Diakses 10 Desember 2011.

Mira. 9 September 2009. Kain Flanel atau Felt. http://Kainflanel/sejarahflanel.htm. Diakses 10 Desember 2011.

Musdalifah. 2009. Pemberdayaan anak Jalanan Melalui program Life Skill Bidang Busana. Artikel pada Prosiding Seminar Nasional Akselerasi Peningkatan Kualitas Sumber Daya manusia melalui Pendidikan Kesejahteraan Keluarga. UPI Bandung, 30 Oktober 2007.

Sulastiano, Harry. Seni dan Budaya. 2008. Grafindo Media Pratama. Jakarta.

Sunflo's. 14 Agustus 2009. Gantungan Kunci Strawberry dari kain Flanel. http://Kainflanel/GantunganKunciStrawberrydariKainFlanel.htm. Diakses 10 Desember 1011.

Schmidlen. Kain Flanel. http://KainFlanel.htm. Diakses 10 Desember 2011.

Rahayu, Endah. 2004. Membuat kreasi fungsional dari kain flannel. Kawan pustaka: Jakarta.

Yuki. 2005. Terampil kriya, flannel. Puspa swara. Jakarta. 